\title{
The experimental production of zinc deficiency in the rat
}

\author{
By R. B. WILLIAMS AND C. F. MILLS \\ Rowett Research Institute, Bucksburn, Aberdeen $A B 2{ }_{9} S B$ \\ (Received 26 Fanuary 1970-Accepted 4 May 1970)
}

\begin{abstract}
I. Techniques for the preparation of a semi-synthetic basal diet suitable for the rapid production of zinc deficiency in the rat are described. The complete diet usually contains between 0.6 and $0.9 \mathrm{ppm} \mathrm{Zn}$.

2. When the unsupplemented diet was fed to weanling rats, growth arrest occurred after 4-5 d; when supplemented with $\mathrm{ZnSO}_{4}$ to provide $\mathrm{I} 2$ or $20 \mathrm{ppm} \mathrm{Zn}$, the rate of growth of rats was similar to that attained in animals given a conventional stock colony diet providing $83 \mathrm{ppm} \mathrm{Zn}$. A study of relationships between dietary $\mathrm{Zn}$ concentration and weight gain in $2 \mathrm{I} d$ suggested that the $\mathrm{Zn}$ requirement of male and female rats for growth on this diet is approximately $x 2$ ppm.

3. The development of $\mathrm{Zn}$ deficiency on diets providing $<\mathrm{I}$ or $3 \mathrm{ppm} \mathrm{Zn}$ was accompanied by poor food consumption and the development of a characteristic cyclic pattern of intake. A significant decline in the variability of daily food intake was observed when the diet was supplemented with $\mathrm{Zn}$ to provide 6, 9 or $\mathrm{i} 2 \mathrm{ppm}$.

4. Studies of the influence of dietary $\mathrm{Zn}$ content upon changes in the $\mathrm{Zn}$ content of a range of tissues and upon whole-body $\mathrm{Zn}$ retention are reported.

5. The above findings are discussed in relation to the problem of defining the severity and duration of $\mathrm{Zn}$ deficiency in animals used for studies on the nature of the metabolic role of $\mathrm{Zn}$.
\end{abstract}

Recent work in this laboratory has been devoted to the study of zinc deficiency in small laboratory mammals and farm livestock. Details of some of our findings on $\mathrm{Zn}$ deficiency in the ruminant have been previously published in this Journal (Mills, Dalgarno, Williams \& Quarterman, 1967). This paper presents details of the methods used to produce $\mathrm{Zn}$ deficiency in rats, and studies of their $\mathrm{Zn}$ requirement for growth. Detailed accounts of the biochemical and pathological changes which occur during the development of deficiency will be the subjects of later communications.

Previous work on the production of $\mathrm{Zn}$ deficiency in laboratory animals has, with few exceptions, relied upon the use of diets containing components known to reduce $\mathrm{Zn}$ availability. Published work contains many discrepancies in statements about the $\mathrm{Zn}$ requirement of the rat, about the nature of clinical signs of deficiency and about the effects of dietary $\mathrm{Zn}$ concentration upon growth rate. These aspects have been fully reviewed by Becker (1967), Macapinlac (1967) and Theuer (1965).

The object of work in progress in this laboratory is to determine the nature of the metabolic lesions in $\mathrm{Zn}$ deficiency. For this it was essential to develop a procedure for inducing $\mathrm{Zn}$ deficiency that would give reproducible results and permit an accurate assessment of the stage of depletion of the animals. Many past studies of the metabolic effects of $\mathrm{Zn}$ deficiency have been carried out on animals depleted of $\mathrm{Zn}$ by a variety of techniques and under conditions in which it is rarely possible to determine the period for which a deficiency of $\mathrm{Zn}$ had altered metabolic activity. A survey of the references cited in the discussion to this paper showed that different investigators had 
used depletion periods ranging from 28 to $150 \mathrm{~d}$ and, in consequence, it is often not possible to determine from the results whether the clinical and metabolic effects described should be regarded as primary or secondary consequences of $\mathrm{Zn}$ deprivation. In our opinion it is these limitations that have given rise to the large number of conflicting reports on the nature of the metabolic roles of $\mathrm{Zn}$.

Our aims in developing the techniques to be described were, first, to achieve a rapid depletion by the use of a diet low in $\mathrm{Zn}$ content rather than by introducing into the diet components known to reduce $\mathrm{Zn}$ availability by formation of complexes, and secondly, to develop a procedure giving reproducible performance during depletion and repletion.

\section{METHODS}

\section{Preparation of diet}

The diet used was essentially that described by Mills \& Murray (I960), modified so as to permit the use of dried egg albumen or purified casein as alternative protein sources. Techniques for the preparation of the purified mineral supplement were modified in the interests of simplicity and the complete technique is described below.

Inorganic salt supplement (major elements). Anhydrous $\mathrm{Na}_{2} \mathrm{HPO}_{4}(86 \mathrm{~g}$ ), anhydrous $\mathrm{KH}_{2} \mathrm{PO}_{4}(82 \mathrm{~g})$ and $\mathrm{KCl}(6 \circ \mathrm{g})$ were dissolved in glass-distilled water to prepare a nearsaturated solution. To this solution was added $\mathrm{MgCl}_{2} \cdot 6 \mathrm{H}_{2} \mathrm{O}(34 \mathrm{~g})$ dissolved in about $25 \mathrm{ml}$ water and then, with vigorous stirring, about Io $\mathrm{ml}$ of a saturated solution of 8-hydroxy-quinoline in ethanol. The solution was transferred to a separatory funnel and extracted six times with $70-80 \mathrm{ml}$ chloroform. The chloroform washings were discarded and a solution of $0.5 \mathrm{~g}$ sodium diethyldithiocarbamate in $5 \mathrm{ml}$ water was added to the aqueous solution which was then washed six times with chloroform. The extraction of the bulk preparation with chloroform continued until no yellow reaction was observed on adding $\mathrm{Cu}^{2+}$ to $\mathrm{I}-2 \mathrm{ml}$ of the aqueous phase.

The purified salt solution was concentrated by evaporation and dried under infrared lamps until a nearly granular material was obtained, and finally the drying was completed in an air oven at $85^{\circ}$. The material was then powdered and stored in airtight bottles. All apparatus used was previously washed in dilute nitric acid and distilled water.

Purified calcium carbonate. The method was that of Mills \& Murray (ig60).

Water-soluble vitamin mixture. The following amounts of water-soluble vitamins were thoroughly mixed with powdered sucrose and stored under refrigeration in an air-tight bottle: thiamine, $0.25 \mathrm{~g}$; pyridoxol, $0.25 \mathrm{~g}$; calcium pantothenate, $4.00 \mathrm{~g}$; folic acid, $0.25 \mathrm{~g}$; biotin, $0.50 \mathrm{~g}$; inositol, $20.00 \mathrm{~g}$; sucrose, $22.75 \mathrm{~g}$. Choline hydrochloride and cyanocobalamin were not included in this premix but were added during the preparation of each batch of diet as described later. This quantity of vitamin mixture was sufficient for $50 \mathrm{~kg}$ of the complete diet. A higher biotin level was used in this diet than in that of Mills \& Murray ( 1960 ) to obviate risks of the appearance of biotin deficiency through the possible presence of avidin in the egg albumen used as the protein source.

Protein source. Spray-dried egg albumen (Messrs Hardie \& Co., Silvermills, Edin- 
burgh) was used as the protein source in most of the studies. This material had a $\mathrm{Zn}$ content within the range of $\mathrm{I}-2 \mathrm{ppm}$ and required no purification.

The complete diet. To make a $10 \mathrm{~kg}$ batch, the following quantities were thoroughly mixed: dried egg albumen, $2 \mathrm{~kg}$; commercial sucrose, $6.6 \mathrm{~kg}$; arachis oil, I kg; purified inorganic salt supplement, $245 \mathrm{~g}$; purified calcium carbonate, $135 \mathrm{~g}$. The following trace elements were finely powdered and mixed with a quantity of powdered sucrose as carrier: $\mathrm{MnSO}_{4} \cdot 4 \mathrm{H}_{2} \mathrm{O}, 2 \cdot 10 \mathrm{~g} ; \mathrm{FeSO}_{4} \cdot 7 \mathrm{H}_{2} \mathrm{O}, 2.60 \mathrm{~g} ; \mathrm{CuSO}_{4} \cdot 5 \mathrm{H}_{2} \mathrm{O}, 0.98 \mathrm{~g}$ (all Specpure quality: Johnson, Matthey Ltd, London), and KI, $0.2 \mathrm{I} g$ (powdered separately with sucrose to prevent reaction with metal salts). The following watersoluble vitamins were added in a premix with sucrose as carrier: vitamin premix (described above), Io g; choline hydrochloride, Io g; cyanocobalamin (Cytamen; Glaxo Research Ltd, Greenford, Middlesex), 250 $\mu \mathrm{g}$. A little arachis oil was used as carrier for: retinol acetate, $42 \mathrm{mg}$; ergocalciferol, $2 \mathrm{mg}$ and $\alpha$-tocopherol acetate, $2 \cdot \circ \mathrm{g}$, dissolved in a small quantity of chloroform. The $\mathrm{Zn}$ content of the complete diet was usually $0 \cdot 6-0.9 \mathrm{ppm}$. Zn-supplemented diets were prepared in the same manner by the addition of $\mathrm{ZnSO}_{4} \cdot 7 \mathrm{H}_{2} \mathrm{O}$ as described later. The diets were stored at $-20^{\circ}$ in I kg packets.

\section{Experimental procedure}

The comments in this paper on the effects of $\mathrm{Zn}$ deficiency on the growth of rats and upon the pattern of food consumption are based on experience gained from work with more than 500 rats. This paper describes in detail the results obtained in two studies in which the influence of different dietary concentrations of $\mathrm{Zn}$ upon performance was assessed and compared with those obtained from a conventional stock colony diet. The opportunity was taken during one experiment to investigate the effects of different dietary $\mathrm{Zn}$ concentrations upon tissue $\mathrm{Zn}$ storage and whole-body $\mathrm{Zn}$ content.

Expt I. Eighteen male and eighteen female weanling rats of the Rowett Institute strain of black-hooded Lister were allocated at random to three groups which were given: group $\mathrm{A}$, basal diet supplemented with $\mathrm{Zn}$ as $\mathrm{ZnSO}_{4} \cdot 7_{7} \mathrm{H}_{2} \mathrm{O}$ to provide a final concentration of $6 \mathrm{ppm} \mathrm{Zn}$; group $\mathrm{B}$, as (A) but given a supplement to provide $20 \mathrm{ppm}$ $\mathrm{Zn}$; group C, Oxoid Stock Colony Diet (H. C. Styles Ltd, Bewdley). The performance of male animals receiving the above diets was compared with that of a further group of six male weanling rats given the unsupplemented $\mathrm{Zn}$-deficient basal diet (group D). Animals were housed individually in Perspex cages with glass-rod floors and were offered food and glass-distilled water $a d l i b$. in glass feeding jars that had been previously rinsed with EDTA solution and glass-distilled water before use. Animals were weighed three times weekly and food intake was recorded daily. The experiment lasted for $35 \mathrm{~d}$.

Expt 2. Thirty male and thirty female weanling rats of the same strain as used in Expt I were allocated at random to the following five treatment groups: initial slaughter group for determination of initial tissue $\mathrm{Zn}$ content; four groups given the basal diet supplemented to 3,6,9 or $12 \mathrm{ppm} \mathrm{Zn}$. In all instances $\mathrm{Zn}$ supplements were added in the form of finely ground $\mathrm{ZnSO}_{4} \cdot{ }_{7} \mathrm{H}_{2} \mathrm{O}$. The management of the experimental animals was as described under Expt $\mathrm{r}$. The experiment with females was 
terminated after $39 \mathrm{~d}$ and that with males after $42 \mathrm{~d}$. Animals were killed by inhalation of diethyl ether if the carcass was required for determination of total body $\mathrm{Zn}$ content or by stunning and exsanguination when the $Z n$ content of the individual organs was to be examined.

\section{Analytical methods}

The $\mathrm{Zn}$ content of diets and of individual organs was determined by atomic absorption spectrophotometry after wet digestion of samples in a nitric acid-perchloric acid mixture. Whole-body $\mathrm{Zn}$ was determined by low-temperature carbonization of carcasses followed by dry ashing at $45^{\circ}$ overnight in a silica-lined muffle furnace. Residual traces of carbon were removed by slowly increasing the temperature to $600^{\circ}$ over a period of $3 \mathrm{~h}$. The ash was dissolved in dilute nitric acid for $\mathrm{Zn}$ determination as above.

\section{RESULTS}

\section{Influence of dietary $Z$ n concentration on weight gain}

Weanling rats of group $\mathrm{D}$ given the unsupplemented basal diet ( $\mathrm{Zn}$ content $0 \cdot 6$ $0.9 \mathrm{ppm})$ grew rapidly for $4-5 \mathrm{~d}(\operatorname{Expt} \mathrm{I}$, Fig. I); no significant increase in weight

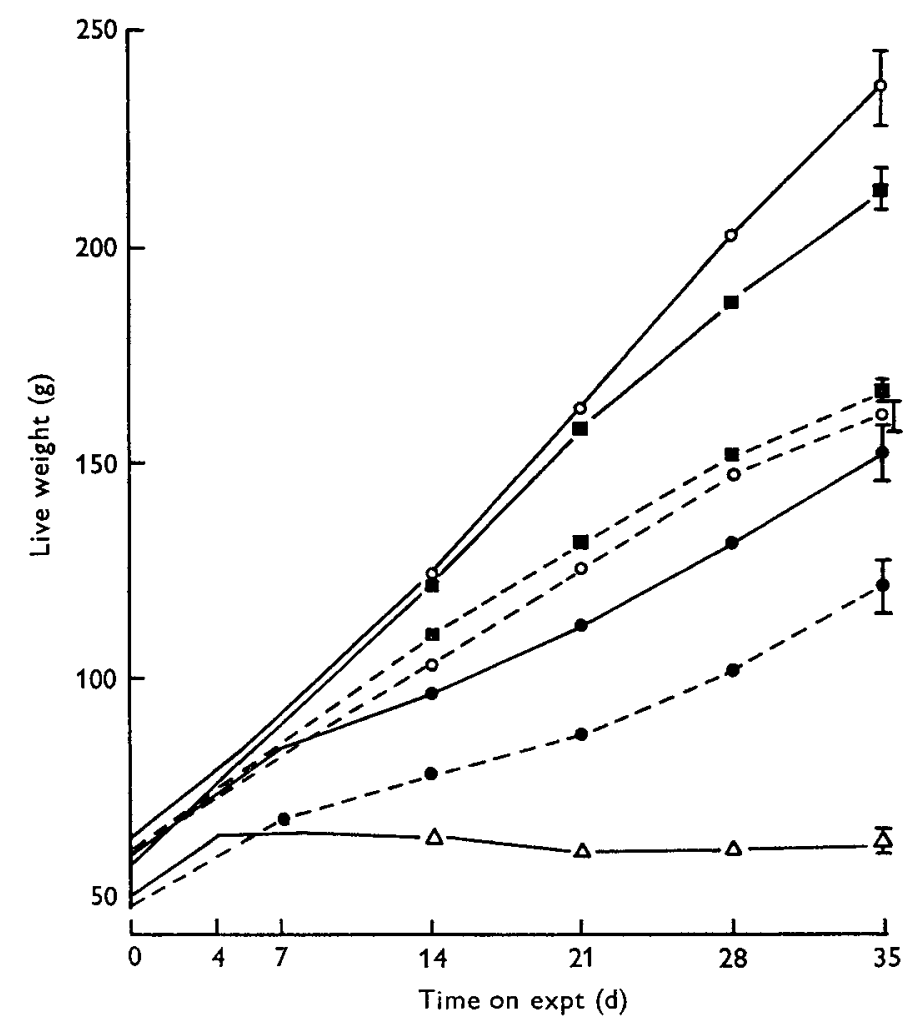

Fig. I. Expt I. A comparison of the weight gain of male and female rats fed from weaning upon a stock colony diet or a semi-synthetic basal diet (see p. 99I) supplemented with zinc. $\triangle$, unsupplemented basal diet ( $<$ I ppm $\mathrm{Zn}$ ); $\bullet$, basal diet supplemented to $6 \mathrm{ppm} \mathrm{Zn} ; 0$, basal diet supplemented to $20 \mathrm{ppm} \mathrm{Zn} ; \mathbf{E}$, stock colony diet $(83 \mathrm{ppm} \mathrm{Zn}) ;-$, $\delta^{\star}$ animals; ---, $q$ animals. The vertical bars indicate the standard errors. 
occurred thereafter during the period of the experiment. At no period during Expt I were there significant differences in the rate of weight gain between animals given the diet providing $20 \mathrm{ppm} \mathrm{Zn}$ (group B) and those receiving a stock colony diet containing $83 \mathrm{ppm} \mathrm{Zn}$ (group C). The diet containing $6 \mathrm{ppm} \mathrm{Zn}$ promoted a significantly slower rate of weight gain than that attained by animals given the diet with 20 or $83 \mathrm{ppm}$ $(P<0.01)$.
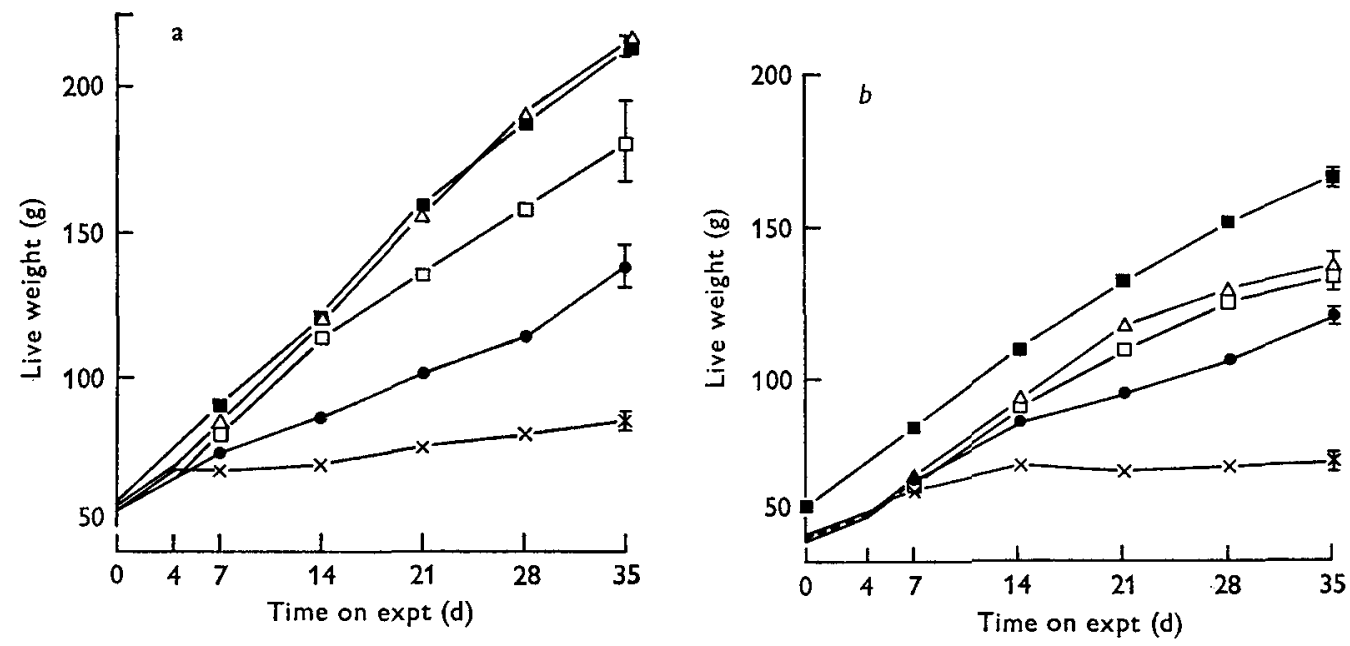

Fig. 2. Expt 2. Influence of the zinc content of a semi-synthetic basal diet upon the growth of (a) male and (b) female rats. $\times, 3 \mathrm{ppm} \mathrm{Zn} ; 0,6 \mathrm{ppm} \mathrm{Zn} ; \square, 9 \mathrm{ppm} \mathrm{Zn} ; \triangle$, I2 ppm $\mathrm{Zn}$.

(घ, stock colony diet; results from Expt r.) The vertical bars indicate the standard errors.

Relationships between the dietary $\mathrm{Zn}$ concentration and live-weight gain obtained in Expt 2 where the concentration of $\mathrm{Zn}$ ranged from 3 to 12 ppm are plotted in Fig. $2 a$ and $b$ for males and females respectively. Rats given diets containing $3 \mathrm{ppm} \mathrm{Zn}$ suffered a decline in growth rate between 7 and $14 \mathrm{~d}$ after the start of the experiment; no further increase in weight occurred thereafter in female animals but males continued to show a very slow increase in weight.

Results obtained with both male and female rats suggested that within the range 6-12 ppm $\mathrm{Zn}$ there was a close relationship between rate of weight increase and dietary $\mathrm{Zn}$ concentration.

In most of our metabolic studies on the role of $\mathrm{Zn}$ we are considering primarily the dramatic early effects of deficiency upon growth and for this work we use young rats that have been maintained on control or deficient diets for periods between $\mathrm{I}$ and $2 \mathrm{I} \mathrm{d}$. Accordingly, the relationships between dietary $\mathrm{Zn}$ concentration and weight increase up to $2 \mathrm{I}$ d derived from both Expts I and 2 have been examined more closely and the results are illustrated in Fig. 3. We feel justified in combining the results for the two experiments as no significant difference in the response to $6 \mathrm{ppm}$ supplementary $\mathrm{Zn}$ was noted between these two experiments in either of the sexes and the response to $12 \mathrm{ppm} \mathrm{Zn}$ in Expt 2 was not different from that obtained with $20 \mathrm{ppm}$ in Expt $\mathrm{r}$, suggesting that the requirement for growth had apparently been met by these higher 
levels of $\mathrm{Zn}$ supplementation. Weight gain during $2 \mathrm{I} \mathrm{d}$ was very closely related to the $\mathrm{Zn}$ content of the diet within the range $3^{-12} \mathrm{ppm}$. For practical purposes the relationship may be regarded as linear with an incremental increase of 1 ppm $\mathrm{Zn}$ promoting a gain of $9.4 \mathrm{~g}$ live weight in males and $6.6 \mathrm{~g}$ in females.

Considering the results of Expt 2, dietary concentrations of Zn below 9 ppm promoted a greatly reduced rate of gain compared with $\mathrm{I} 2 \mathrm{ppm}(P<0 \cdot 0 \mathrm{r})$ in both males and females. Weight gain on $9 \mathrm{ppm}$ dietary $Z \mathrm{n}$ was significantly less than that on $12 \mathrm{ppm}$ in males $(P<0.05)$ but not in females ( $1 \cdot 10>P>0.05)$. Weight gain appeared to be independent of the dietary $\mathrm{Zn}$ concentration above $\mathrm{I} 2 \mathrm{ppm}$ and in Expt $\mathrm{I}$ the gain at $20 \mathrm{ppm} \mathrm{Zn}$ was not significantly different from that obtained on the stock colony diet providing $83 \mathrm{ppm}$.

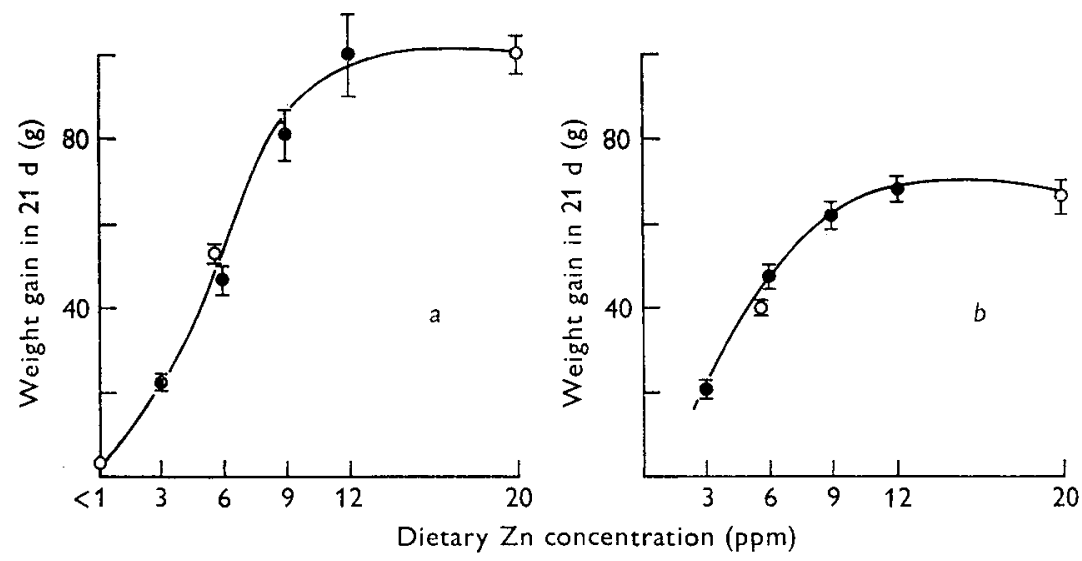

Fig. 3. Influence of dietary zinc concentration on the weight gain of $(a)$ male and $(b)$ female rats during a $2 \mathrm{I}$ d period from weaning. $O$, values from Expt $\mathrm{I} ; \boldsymbol{C}$, values from Expt 2 . The vertical bars indicate the standard errors; diet, semi-synthetic basal (see p. 99I) offered ad lib.

\section{Effects of dietary $Z n$ concentration on food consumption}

We have consistently noted during our work with young rats given $\mathrm{Zn}$-deficient basal diets that food intake falls after $4-5 \mathrm{~d}$ (i.e. at the time that the check in liveweight gain is first noted). Thereafter, a characteristic cyclic pattern of food intake develops as in Fig. 4, which illustrates the food intake of typical individual animals from each group in Expt 2 and from group D of Expt I. Under our conditions, the establishment of this pattern of food consumption constitutes a very reliable guide to the time of onset of $\mathrm{Zn}$ deficiency in an animal.

This pattern of food intake was still apparent when the diet provided $3 \mathrm{ppm} \mathrm{Zn}$. Food intake became progressively less variable as the dietary $\mathrm{Zn}$ concentration was raised above $6 \mathrm{ppm}$ and the cyclic pattern was not apparent when the diet contained 9 or 12 ppm Zn.

To obtain a less subjective statement of these patterns, values for food intake were analysed on the basis of the following findings and assumptions:

(I) Within a treatment the daily variations of food intake about a regression of 
intake against days on treatment did not alter significantly with time or weight of rat.

(2) Food intake increased with increase in body-weight; accordingly, linear regression analysis of food intake on days was carried out to calculate the intake and variability of intake of each rat at a standard live weight ( $80 \mathrm{~g}$ for males and $70 \mathrm{~g}$ for females).

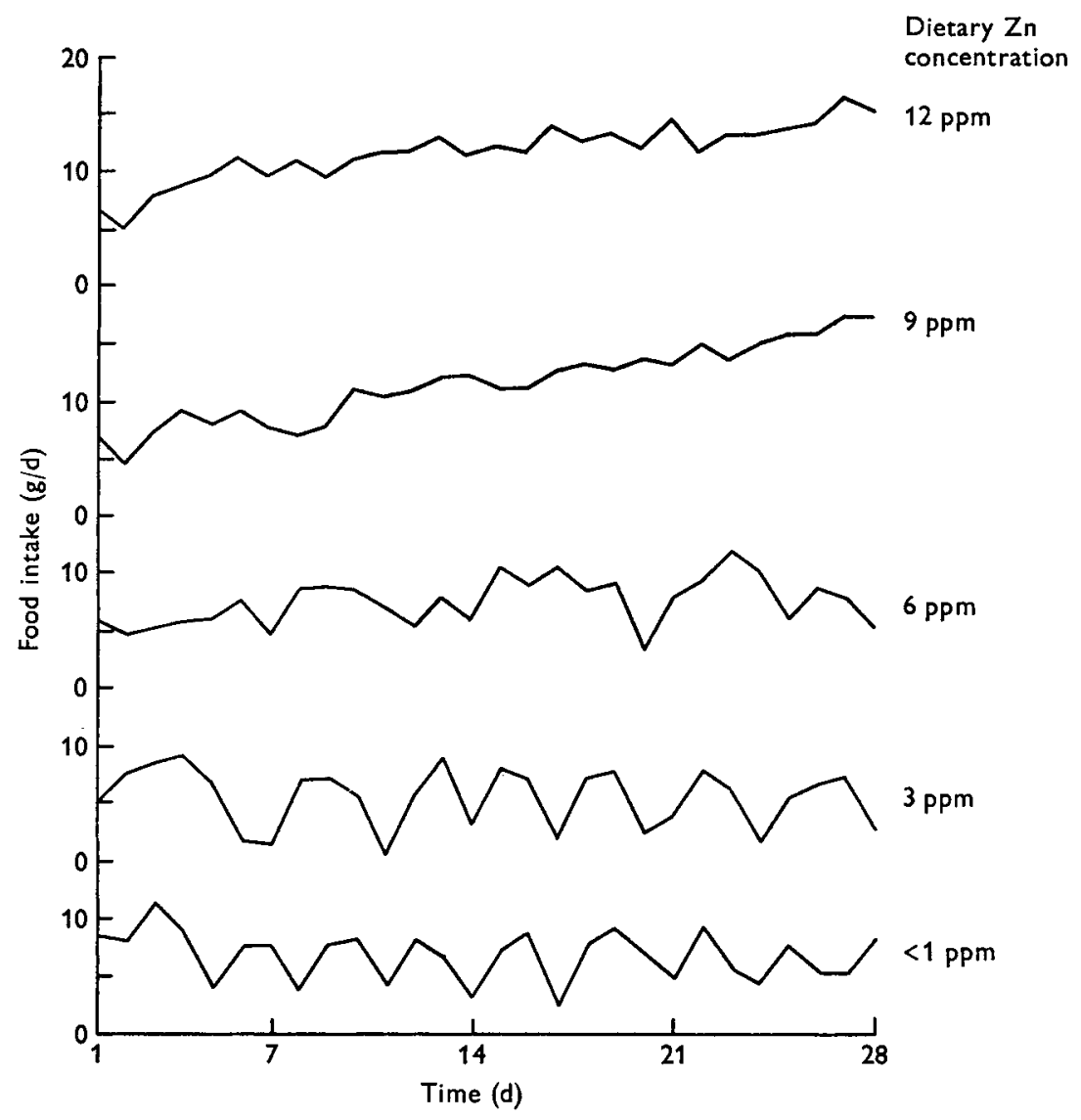

Fig. 4. Characteristic patterns of daily food intake by individual male rats fed on a zincdeficient semi-synthetic basal diet supplemented with different quantities of $\mathrm{Zn}$. Values for representative animals from each group of Expt $2\left(3^{-12} \mathrm{ppm} \mathrm{Zn}\right)$ and from group D of Expt I.

(3) To study the effect of dietary $\mathrm{Zn}$ concentration upon 'cycling' of food intake the definition of a cycle was based upon the finding, from other experiments with rats maintained upon the same basal diet adequately supplemented with $\mathrm{Zn}\left(4^{\circ} \mathrm{ppm}\right)$, that the standard deviation of daily intake was $\pm 0.5 \mathrm{~g} / \mathrm{d}$ during the period covered by Expt 2. A cycle was defined as the period between days of high intake where one peak was followed by a fall in intake of $>2 \times$ SD within $2 \mathrm{~d}$ and a subsequent rise of $>2 \times$ SD within $2 \mathrm{~d}$. 
Results obtained from the analysis of values originating from Expt 2 are presented in Table $I$.

Both the SD and coefficient of variation of daily food intake of male and female rats declined progressively with increase in the concentration of dietary $\mathrm{Zn}$ and treatment

Table I. Expt 2. Influence of dietary zinc concentration upon the variability of food intake by the rat

(a) Mean daily food intake ( $\mathrm{g}$ ) at $80 \mathrm{~g}$ (males) and $70 \mathrm{~g}$ (females) live weight and the coefficient of variation of intake $(\%)$

\begin{tabular}{ccccc}
\multicolumn{5}{c}{ Value at dietary Zn concentration (ppm) of } \\
\cline { 2 - 5 } Sex & 3 & 6 & 9 & 12 \\
$\delta$ & $5 \cdot 7$ & $7 \cdot 7$ & $9 \cdot 6$ & $10 \cdot 1$ \\
& $44 \%$ & $33 \%$ & $14 \%$ & $13 \%$ \\
+ & $5 \cdot 8$ & $8 \cdot 1$ & $8 \cdot 3$ & $8 \cdot 5$ \\
& $40 \%$ & $27 \%$ & $22 \%$ & $17 \%$
\end{tabular}

Significance of treatment effects

(b) Characteristics of food intake cycles

\begin{tabular}{|c|c|c|c|}
\hline Sex & $\begin{array}{c}\text { Dietary } \mathrm{Zn} \\
\text { concentration } \\
(\mathrm{ppm})\end{array}$ & $\begin{array}{l}\text { Cycles detected/rat } \\
\text { in } 24 \mathrm{~d} \dagger\end{array}$ & $\begin{array}{c}\text { Mean amplitude } \\
(\mathrm{g})\end{array}$ \\
\hline$\delta$ & $\begin{array}{l}3 \\
6\end{array}$ & $\begin{array}{l}4 \cdot 4 \pm 0 \cdot 2 \\
4 \cdot 6 \pm 0 \cdot 6\end{array}$ & $\begin{array}{l}6.04 \pm 0.41 \\
6.04 \pm 0.71\end{array}$ \\
\hline & $\begin{array}{r}9 \\
12\end{array}$ & $\begin{array}{l}3.5 \pm 0.3 \\
2 \cdot 0 \pm 0.5\end{array}$ & $\begin{array}{l}2.53 \pm 0.13 \\
3.88 \pm 0.70\end{array}$ \\
\hline 우 & $\begin{array}{r}3 \\
6 \\
9 \\
12\end{array}$ & $\begin{array}{l}5 \cdot 0 \pm 0 \cdot 4 \\
4 \cdot 8 \pm 0 \cdot 5 \\
2 \cdot 6 \pm 0 \cdot 4 \\
3 \cdot 2 \pm 0.5\end{array}$ & $\begin{array}{l}5.85 \pm 0.29 \\
4.46 \pm 0.19 \\
4.82 \pm 0.68 \\
3.32 \pm 0.32\end{array}$ \\
\hline
\end{tabular}

effects were statistically significant (Table $\mathrm{I} a$ ). Increasing the dietary $\mathrm{Zn}$ concentration above $6 \mathrm{ppm}$ reduced the number of cycles of high and low food intake as defined above; the period of such cycles increased with an accompanying decrease in amplitude (Table $\mathrm{I} b$ ). While appreciating the limitations of the methods employed in this analysis we are nevertheless of the opinion that the results obtained present a substantially accurate picture of the behaviour of $\mathrm{Zn}$-deficient rats with the possible exception that the rigorous criteria proposed for the definition of a cycle of intake may lead to the detection of fewer cycles than does a subjective assessment of performance based upon graphically presented results (e.g. Fig. 4).

Values for food consumption over the whole period of Expt 2 and for the ratio of food consumed per g live-weight gain for the animals of Expt 2 receiving 3-12 ppm Zn are presented in Fig. 5. Food consumption by either sex was positively related to dietary $\mathrm{Zn}$ content within the range 3-9 ppm. The differences between total food consumption on 3 and $6 \mathrm{ppm}$ and between 6 and $9 \mathrm{ppm}$ were significant at $P<0.01$ and 0.05 respectively. No influence of dietary $\mathrm{Zn}$ content above $\mathrm{I} 2 \mathrm{ppm}$ on food consumption has been observed in other experiments. A very poor food conversion ratio was obtained in rats given diets providing $3 \mathrm{ppm} \mathrm{Zn}$; a very significant improvement in conversion ratio was observed in rats given diets providing $6 \mathrm{ppm} \mathrm{Zn}$ or more. 


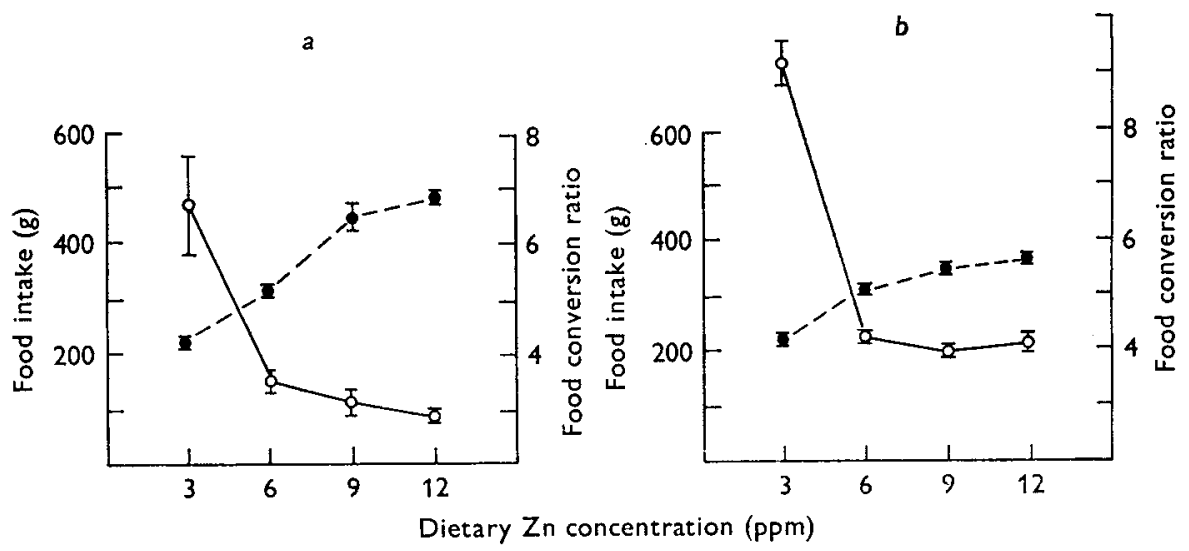

Fig. 5. Expt 2. Influence of dietary zinc concentration upon food conversion ratio (food consumed $(g) \div$ weight gained $(g))$ and mean food consumption in $(a)$ male and $(b)$ female rats during a $39 \mathrm{~d}$ experimental period. $\mathrm{O}-\mathrm{O}$, food conversion ratio; $-\longrightarrow$, food intake. The vertical bars indicate the standard errors.

\section{Influence of dietary $Z n$ concentration on tissue $Z n$}

Values for the influence of dietary $\mathrm{Zn}$ concentration on the $\mathrm{Zn}$ concentration of the carcass at the end of Expt 2 are given in Table 2 together with estimates of the percentage retention of dietary $\mathrm{Zn}$. No major changes in total body $\mathrm{Zn}$ concentration were noted during the experiment but weanling male and female rats analysed at the beginning of the experiment had slightly higher mean body $\mathrm{Zn}$ concentrations than animals of the same sex analysed at the end regardless of diet. Throughout the experiment the mean values for female rats were higher than those for males. Within each sex the different concentrations of $\mathrm{Zn}$ in the diet had no consistent effect on final total body $\mathrm{Zn}$ concentration. Estimates of the percentage retention of dietary $\mathrm{Zn}$ were derived from initial and final whole-body $\mathrm{Zn}$ concentrations, from initial and final body-weights and from measurements of food consumption. Male animals showed a progressive decline in retention of dietary $\mathrm{Zn}$ from $73 \%$ on the diet providing $3 \mathrm{ppm} \mathrm{Zn}$ to about $48 \%$ at $12 \mathrm{ppm}$; a less consistent pattern was obtained in estimates of retention by female animals particularly at low levels of supplementary $\mathrm{Zn}$, and we are unable to explain the apparent discrepancy between the results for males and females receiving 3 and $6 \mathrm{ppm} \mathrm{Zn}$. In both sexes the estimates of retention were very variable when the diet provided 3 or $6 \mathrm{ppm} \mathrm{Zn}$ but were more consistent at concentrations of 9 and $\mathrm{i} 2 \mathrm{ppm}$.

The concentrations of $\mathrm{Zn}$ in the individual tissues are presented in Table 3 . In most organs the influence of dietary $\mathrm{Zn}$ concentration upon tissue $\mathrm{Zn}$ concentration is small. Results for animals receiving 3 or $6 \mathrm{ppm} \mathrm{Zn}$ suggest that, with the exception of the liver, where a small increase in $\mathrm{Zn}$ concentration was observed, the diet providing $6 \mathrm{ppm} \mathrm{Zn}$ produced a decline in the $\mathrm{Zn}$ concentration of muscle, spleen, heart and bone. The progressive increase of the dietary $\mathrm{Zn}$ level from 6 to $12 \mathrm{ppm}$ substantially increased the concentration of $\mathrm{Zn}$ in pancreas and bone, and to a lesser extent, in the testes. Changes in the $\mathrm{Zn}$ concentration of other organs in response to dietary $\mathrm{Zn}$ 
levels in the range of 6-12 ppm were small and this, coupled with the relatively small numbers of animals used in this investigation, prevents us from drawing firm conclusions regarding the nature of these minor trends.

Comparison of the values for weanling rats with those obtained 6 weeks later for rats receiving $12 \mathrm{ppm} \mathrm{Zn}$ (a level apparently sufficient to meet requirements of growth) suggests that the $\mathrm{Zn}$ concentration in most organs increases with age in the young growing rat. During the period of Expt 2 the largest increases were noted in the

Table 2. Expt 2. Whole-body zinc concentration and $Z n$ retention of rats fed on semi-synthetic diets differing in $Z n$ content

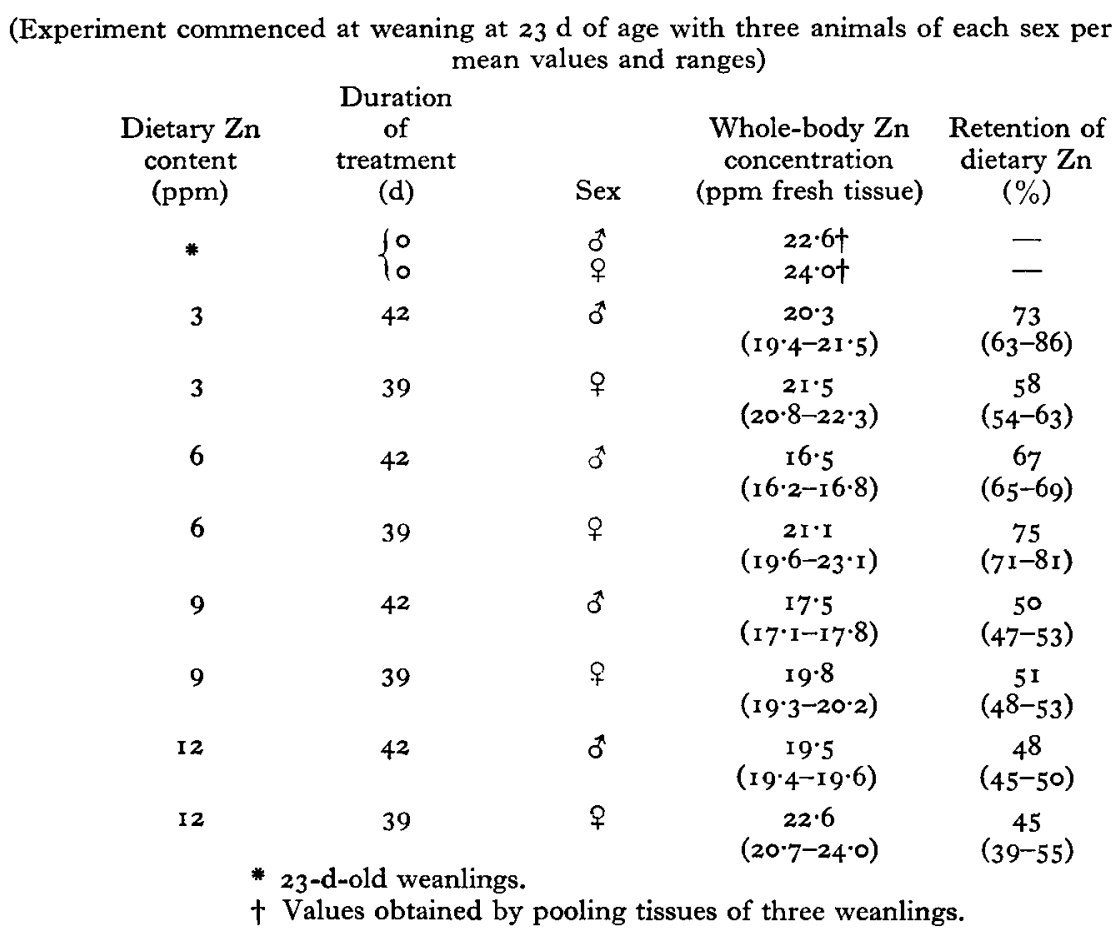

pancreas and testes (increases of $6 \mathrm{I}$ and ${ }_{51} \%$ respectively); a substantial increase in the $\mathrm{Zn}$ concentration of bone ( $43 \%$ ) was noted and the $\mathrm{Zn}$ concentration of muscle, heart, liver and spleen showed small increases (within the range of $15-24 \%$ ). In contrast, a marked decline in the $\mathrm{Zn}$ concentration of lung tissue was noted.

The absence of significant changes in the concentration of $\mathrm{Zn}$ in the whole body between weaning and the end of Expt 2 (Table 2) suggests that tissues known to be very rich in $\mathrm{Zn}$, e.g. hair, skin, eye (De Vuyst, Vanbelle, Arnould, Vervack \& Moreels, 1960), may make a decreasing contribution to the total body $\mathrm{Zn}$ as growth proceeds, thus offsetting the substantial increases found in the concentration of $\mathrm{Zn}$ in pancreas, bone and testes and the smaller increases found in other organs. 
Vol. 24

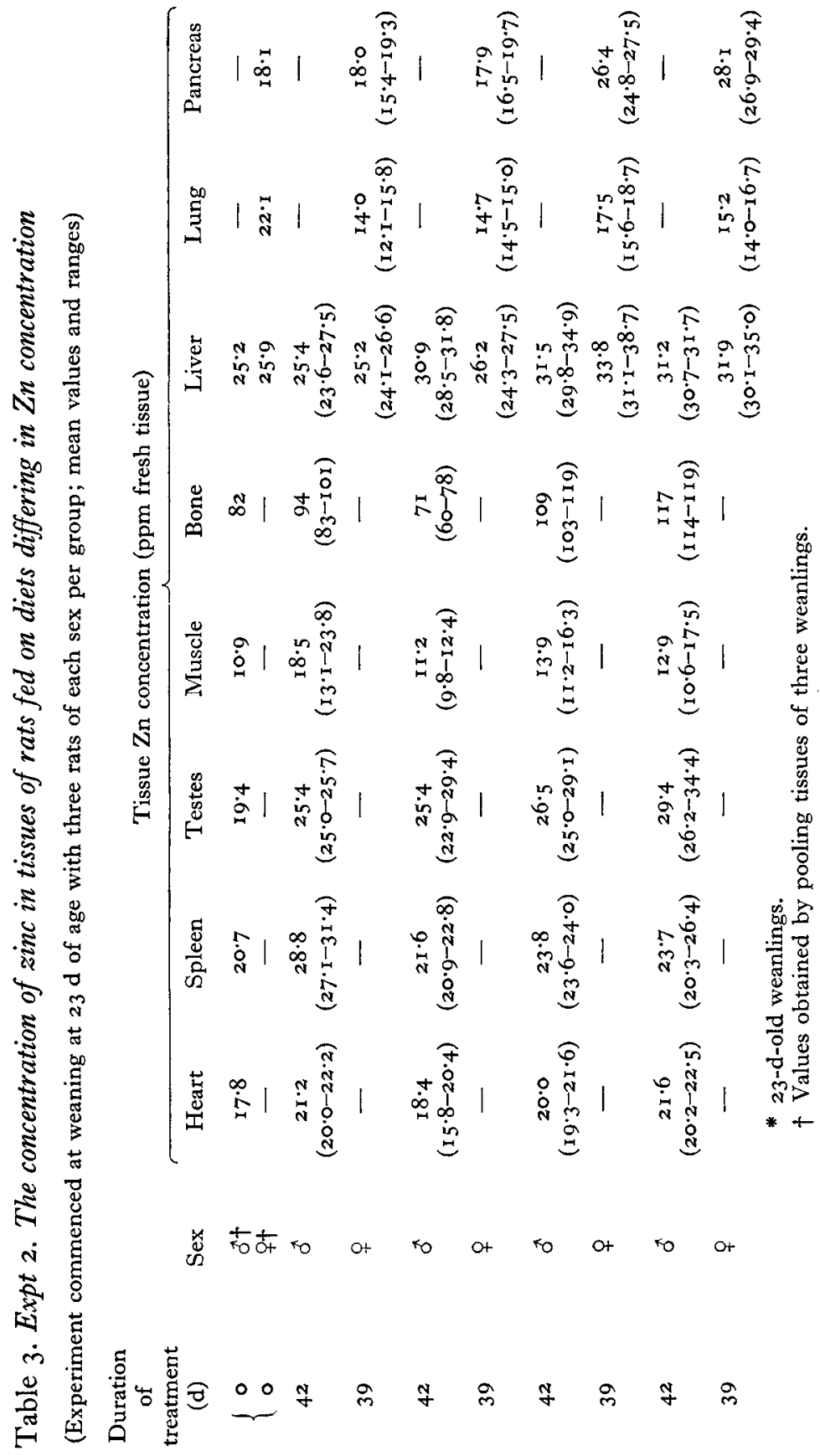

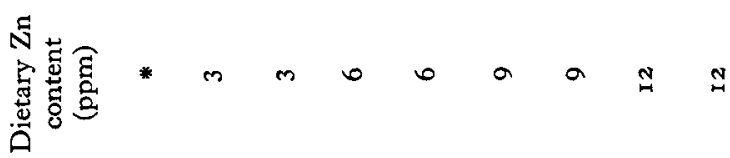




\section{DISCUSSION}

The most striking feature of the performance of weanling rats fed on our semisynthetic $\mathrm{Zn}$-deficient basal diet was the failure of growth and the simultaneous onset of a poor and erratic food intake $4-5 \mathrm{~d}$ after the introduction of the diet. It has been previously noted in work with calves and sheep that the effects of $\mathrm{Zn}$ deficiency appear very rapidly in animals fed a ration containing only about I ppm $\mathrm{Zn}$ (Mills et al. 1967). The rapidity with which these effects appear in both the ruminant and the rat contrasts strongly with the results obtained in experimental work with the trace elements iron, copper and manganese where adverse effects on growth appear only after more prolonged depletion.

The development of a poor appetite and the establishment of an erratic pattern of food consumption with cycles of low and high intake appearing with a frequency of from 3.5 to $4 \mathrm{~d}$ has, in our experience, been an invariable accompaniment of the development of $\mathrm{Zn}$ deficiency in the rat. Other workers have commented upon the reduction in food intake of the $\mathrm{Zn}$-deficient rat but we are not aware of any previous observations which suggest the establishment of a cyclic pattern of eating. This may be due to the use by others of diets which are not sufficiently low in $\mathrm{Zn}$ to produce the effects we have observed.

A conflict of opinion exists in published literature upon the effects of $\mathrm{Zn}$ deficiency on food conversion ratios. Theuer ( 1965 ) working with $\mathrm{Zn}$-deficient rats given a diet based upon hydrolysed casein and containing $\mathrm{I} \cdot \mathrm{I}$ ppm $\mathrm{Zn}$ found no decline in the efficiency of food conversion as deficiency appeared. On the other hand, Prasad, Oberleas, Wolf \& Horwitz ( 1967 ) using a diet based upon C-I assay protein and providing ro ppm $\mathrm{Zn}$ found a decline in the efficiency of food conversion in deficient animals compared with pair-fed controls. It is difficult to resolve this discrepancy, particularly since the rates of weight gain of the animals used by the two investigators were very similar (79 $\mathrm{g}$ in $28 \mathrm{~d}$ (Theuer, 1965); $85 \mathrm{~g}$ in $28 \mathrm{~d}$ (Prasad et al. 1967)) suggesting that the amounts of 'available' $\mathrm{Zn}$ in the experimental diets used by the two groups of workers were similar. Our results presented in Fig. 5 suggest that when the diet provides between 6 and $12 \mathrm{ppm} \mathrm{Zn}$ there is little relationship between food conversion ratio and dietary $\mathrm{Zn}$ content but when the diet provides less than $6 \mathrm{ppm}$ a marked decline in the efficiency of food conversion occurs. These results suggest that when the ration provides less than $6 \mathrm{ppm} \mathrm{Zn}$ there arises a distinct metabolic defect which impairs food utilization but that above $6 \mathrm{ppm}$ the relationships between dietary $\mathrm{Zn}$ and weight gain are almost entirely a consequence of the influence of dietary $\mathrm{Zn}$ content upon food intake.

The above observations on the influence of dietary $\mathrm{Zn}$ level on food consumption, eating pattern and food conversion ratio are important in relation to the many discrepancies which have arisen from previous attempts to study the nature of metabolic lesions in the $\mathrm{Zn}$-deficient rat. We have suggested elsewhere that some of these discrepancies may arise from inadequate experimental control of differences in the pattern of food intake (Mills, Quarterman, Chesters, Williams \& Dalgarno, r969).

The importance of clearly defining the degree of $\mathrm{Zn}$ deficiency induced for meta- 
bolic investigations is illustrated by our findings on changes in food conversion efficiency with $\mathrm{Zn}$ intake. Judged solely upon the rate of live-weight gain, animals receiving $9 \mathrm{ppm} \mathrm{Zn}$ in Expt 2 would be deemed to be $\mathrm{Zn}$-deficient in that the rate of growth was retarded. Since the food conversion ratio remains relatively constant when the diet provides more than $6 \mathrm{ppm} \mathrm{Zn}$, investigational work on rats giving a response similar to that obtained with our animals receiving $9 \mathrm{ppm}$ would, we feel, ultimately reveal the nature of the role of $\mathrm{Zn}$ in regulating food intake. Such studies would not, however, give any indication of the nature of metabolic lesions responsible for the more severe and direct effects of $\mathrm{Zn}$ deficiency upon tissue growth which only arise when the diet contains less than $6 \mathrm{ppm}$.

Our studies suggest that the $\mathrm{Zn}$ requirement of the young weanling rat for growth is approximately $12 \cdot 5^{-1} 3 \mathrm{ppm}$ in both males and females. This estimate agrees closely with that of Forbes \& Yohe (1960) who found that the $\mathrm{Zn}$ requirement of the young rat for growth was approximately $12 \mathrm{ppm}$ when the diet was based upon either casein or egg albumen as protein source. However, Underwood (1962) quotes unpublished work of an Australian group (CSIRO, 195I-2) as claiming that a minimum dietary level of about $2 \mathrm{ppm} \mathrm{Zn}$ is required for the young rat. The nature of the diet was not stated, nor have further details of this work ever been published. Other evidence that the $\mathrm{Zn}$ requirement may be of the order of the figures quoted by Forbes \& Yohe (I g60) and ourselves is provided by the results of Macapinlac (1967) who, using a diet based upon purified casein supplemented with $20 \mathrm{ppm} \mathrm{Zn}$, achieved a good rate of live-weight gain in young animals ( $124 \mathrm{~g}$ gain in $3 \mathrm{I} \mathrm{d}$ ). It is impossible to make generalizations on the $\mathrm{Zn}$ requirement of the rat from any published work in which diets have been based upon protein sources which contain the $\mathrm{Zn}$-binding agent, phytic acid, as a contaminant, with the possible exception again of the critical work of Forbes \& Yohe (1960) who estimated that the requirement was about $18 \mathrm{ppm}$ when soya-bean protein was used as a nitrogen source. Here, however, without determination of the content of phytic acid, it is not possible to make an accurate statement of requirement, and others (e.g. Swenerton \& Hurley, 1968) have suggested that as much as I0o ppm $\mathrm{Zn}$ may be needed for satisfactory growth and development under such circumstances.

Our observations on the effect of low $\mathrm{Zn}$ intakes on bone $\mathrm{Zn}$ levels are in general agreement with those of other workers (Prasad et al. I967; Millar, Fischer, Elcoate \& Mawson, 1958). Where differences in the magnitude of changes in bone $\mathrm{Zn}$ are apparent in comparing the above studies this is probably a consequence of differences in duration of experiments and dietary $\mathrm{Zn}$ levels. There is, nevertheless, agreement that dietary $\mathrm{Zn}$ concentration has an influence upon bone $\mathrm{Zn}$ concentration. Smaller changes in testicular $\mathrm{Zn}$ concentration appear to result from changes in dietary $\mathrm{Zn}$ level and here again our results in general reflect those of Prasad et al. (1967), Millar et al. (1958) and also those of Macapinlac, Pearson \& Darby (1966). In our experiment smaller changes in $\mathrm{Zn}$ concentration were noted possibly owing to the shorter period of the experiment and the smaller differences in dietary $\mathrm{Zn}$ content investigated in our work. We are not aware of studies similar to our own on the influence of very low dietary $\mathrm{Zn}$ concentrations on pancreatic $\mathrm{Zn}$ in the rat. Clear 
evidence was obtained that diets providing only 3 or $6 \mathrm{ppm} \mathrm{Zn}$ resulted in a very substantial decrease in pancreatic $\mathrm{Zn}$ compared with diets providing 9 or $\mathrm{I} 2 \mathrm{ppm}$. This is of interest in view of our earlier observations (Mills, Quarterman, Williams, Dalgarno \& Panić, I967) on the decline in the activity of the Zn-containing enzyme, carboxypeptidase, in the pancreas of the $\mathrm{Zn}$-deficient rat. It now appears possible that the rapid decline in activity of this enzyme during $\mathrm{Zn}$ depletion may be associated with a decrease in the amount of $\mathrm{Zn}$ locally available for incorporation into the apoenzyme. This conclusion must, however, be regarded as tentative as Reinhold, Kfoury \& Thomas (1967), using rats given diets based upon purified casein and gelatin and moderately deficient in $\mathrm{Zn}$ (from 2 to $4.3 \mathrm{ppm}$ ) and which promoted an appreciable gain of weight by 'deficient' animals, found no difference in the Zn concentration of the pancreas between animals fed the unsupplemented diet and diets containing 20 or $30 \mathrm{ppm} \mathrm{Zn}$.

We, like Prasad et al. (1967) and Reinhold et al. (1967), have found that a low $\mathrm{Zn}$ intake is reflected by a small reduction in the $\mathrm{Zn}$ concentration of liver tissue; on the other hand, Macapinlac ( 1967 ) found that $\mathrm{Zn}$ deficiency was accompanied by a small increase in liver $\mathrm{Zn}$ concentration compared with ad lib. or pair-fed control animals. In none of the other tissues we examined was there evidence of any clear relationship between dietary $\mathrm{Zn}$ content and tissue $\mathrm{Zn}$ concentration.

The studies we and others have carried out on changes in tissue $\mathrm{Zn}$ concentration during the development of deficiency have contributed very little to our understanding of the primary site of action of $\mathrm{Zn}$ in the animal or to an understanding of why some effects of the deficiency appear so rapidly compared with those of many other nutrient deficiencies. We are faced with explaining why the animal responds so quickly to a suboptimal $\mathrm{Zn}$ supply when apparently many tissues still contain an appreciable quantity of $\mathrm{Zn}$. The speed of response to a deficient diet, in our case 4-5 d, suggests that the role of $\mathrm{Zn}$ in an organ of high metabolic activity is being impaired and yet, of the tissues we have examined that would fall into this category, only pancreas suffered an appreciable loss of $\mathrm{Zn}$ during the experimental period of approximately $30 \mathrm{~d}$. Other studies on the ruminant (Mills et al. x967) and the rat (Swenerton \& Hurley, I968) have shown that the plasma $\mathrm{Zn}$ concentration falls extremely rapidly when the animal is fed on a $\mathrm{Zn}$-deficient diet. It thus appears probable that the primary site of action of $\mathrm{Zn}$ which is failing in activity during the early stages of the deficiency syndrome must contain $\mathrm{Zn}$ in a form freely exchangeable with $\mathrm{Zn}$ circulating in the plasma. We are ignorant of the location of this functional site and the evidence available to date suggests that before further progress in this field is achieved a more sophisticated approach towards the study of tissue $\mathrm{Zn}$ exchange and changes in local $\mathrm{Zn}$ concentration during depletion must be developed.

The authors thank Miss Irene Hird and Miss Lynda Pilling for their technical assistance during this work and thank Miss Florence Maitland for her careful work in maintaining our experimental animals. We are indebted to Dr J. K. Chesters for devising and undertaking the analysis of results on daily food consumption and to Mr I. McDonald for his advice on this problem. 


\section{REFERENCES}

Becker, W. M. ( 1967 ). Effects of zinc deficiency in the rat on the binding of tissue zinc and on the synthesis of DNA, RNA and protein. PhD Thesis, University of Wisconsin.

CSIRO (1951-2). Rep. Commonw. scient. ind. Res. Org. Aust. (quoted by Underwood, 1962).

De Vuyst, A., Vanbelle, M., Arnould, R., Vervack, W. \& Moreels, A. (1960). Agricultura, Louvain 8, 609 .

Forbes, R. M. \& Yohe, M. (1960). F. Nutr. 70, 53 .

Macapinlac, M. P. (1967). Studies on some effects of zinc deficiency in the rat and squirrel monkey (Samiri sciureus). PhD Thesis, Vanderbilt University.

Macapinlac, M. P., Pearson, W. N. \& Darby, W. J. (1966). In Zinc Metabolism [A. S. Prasad, editor]. Springfield, Ill.: Thomas.

Millar, M. J., Fischer, M. I., Elcoate, P. V. \& Mawson, C. A. (1958). Can. F. Biochem. Physiol. $36,557$. Mills, C. F., Dalgarno, A. C., Williams, R. B. \& Quarterman, J. (1967). Br. F. Nutr. 21, 75 r.

Mills, C. F. \& Murray, G. (1960). F. Sci. Fd Agric. II, 547.

Mills, C. F., Quarterman, J., Chesters, J. K., Williams, R. B. \& Dalgarno, A. C. (1969). Am. J. clin. Nutr. 22, 1240.

Mills, C. F., Quarterman, J., Williams, R. B., Dalgarno, A. C. \& Panić, B. (1967). Biochem. F. 102, 7 I2. Prasad, A. S., Oberleas, D., Wolf, P. \& Horwitz, J. P. (1967). F. clin. Invest. 46, 549.

Theuer, R. C. (1965). A study of metabolic alterations in the zinc deficient rat. PhD Thesis, University of Wisconsin.

Reinhold, J. G., Kfoury, G. A. \& 'Thomas, T. A. (1967). 7. Nutr. 92, I73.

Swenerton, H. \& Hurley, L. S. (1968). F. Nutr. 95, 8.

Underwood, E. J. (1962). Trace Elements in Human and Animal Nutrition 2nd ed. New York and London: Academic Press. 